\title{
Degree of financialization and energy efficiency in Sub-Saharan Africa: do institutions matter?
}

\author{
Philip Kofi Adom"(D, Franklin Amuakwa-Mensah² and Salome Amuakwa-Mensahn, 3,4
}

\footnotetext{
*Correspondence: adomonline@ yahoo.co.uk; padom@gimpa.edu.gh 'Department of Development Policy, School of Public Service and Governance, Ghana Institute of Management and Public Administration (GIMPA), Accra, Ghana

Full list of author information is available at the end of the article
}

\begin{abstract}
The United Nations Sustainable Development Goal 7 emphasizes the need for economies around the world to double their efforts in energy efficiency improvements. This is because improvements in energy efficiency can trigger economic growth and considered as one of the 'green' growth strategies due to its carbon free content. To this end, some empirical studies have investigated the nexus between economic growth and energy efficiency, but the effects of the latter on financial indicators have not been sufficiently studied in the literature, at least in developing economies like Africa. This study examines the effect of energy efficiency improvements on commercial bank profitability under different political regimes (i.e., autocratic and democratic political regimes); something previous literature had neglected. The study uses panel data, consisting of 43 African countries and the simultaneous System Generalized Method of Moments. We found that energy efficiency improvement is more likely to induce higher bank profitability in political institutions with the characteristics of centralization of power compared with those with decentralization of power. Furthermore, for the banking sector, the findings suggest that energy utilization behavior of clients should be included in the loan or credit valuation process. For the government, the agenda of energy efficiency should be aggressively pursued while taking cognizance of creating a political environment that weans itself from a 'grandfathering' behavior.
\end{abstract}

Keywords: Bank performance, Energy efficiency, Institution, Sub-Saharan Africa JEL: G15, G21, Q43

\section{Springer Open}

\section{Introduction}

The aim of this study is to examine the effect of energy intensity (an indicator of energy efficiency) on commercial bank profitability under different political institutional regimes in Africa. The financial sector, through the functions of resource mobilization, efficient use of resources, pooling and reducing risk, and directing investment decisions, improves the real sector and enables economic growth. Since the liberalization of the financial sectors in Africa in the late eighties and nineties, Africa's financial sector has contributed positively to the growth in the real sector and economy to a great extent (Senbet and Otchere 2010).

(c) The Author(s). 2020 Open Access This article is licensed under a Creative Commons Attribution 4.0 International License, which permits use, sharing, adaptation, distribution and reproduction in any medium or format, as long as you give appropriate credit to the original author(s) and the source, provide a link to the Creative Commons licence, and indicate if changes were made. The images or other third party material in this article are included in the article's Creative Commons licence, unless indicated otherwise in a credit line to the material. If material is not included in the article's Creative Commons licence and your intended use is not permitted by statutory regulation or exceeds the permitted use, you will need to obtain permission directly from the copyright holder. To view a copy of this licence, visit http://creativecommons.org/licenses/by/4.0/. 
However, compared with Europe, Asia and the Americas and Caribbean, the financial sector in SSA is not well-developed (Amuakwa-Mensah et al. 2018; Green 2013).

In this region, immense development and financial gaps still exist in the financial sector (Allen et al. 2016). For many of the financial indicators, such as financial depth, financial intermediation, degree of financial penetration, and non-performing loans (NPLs), the performance of SSA has been the lowest in the world (Muñoz et al. 2012). ${ }^{1}$ These factors make the financial sector (especially the banking sector) in Africa, shallow compared with other regions. Given that development of the financial sector contributes significantly to economic growth, a study that investigates the causal factors of financial development is very critical, more importantly, when considering the important role of energy efficiency improvements, which have significant implications on loan underwriting rules as well as individuals' decisions to invest in energy efficiency projects (Adom et al. 2019a, b).

Theoretically, the link between a bank's profitability and energy efficiency dates back to the neoclassical theory of production. Cost efficiency achieved through input-use efficiency increases the competitive position of the firm, its market share, and, consequently, its profit. Given that energy is used as an input in the production processes of both financial and nonfinancial sectors, achieving technical efficiency in energy use could increase the cost efficiency of banks and their profits. Sleuwagenn and Goedhuys (2003) noted that efficiency gains achieved in inputs can translate into a higher competitive position, market share, and profit for banks. Bearing this in mind, in this study, we identify three main transmission mechanisms through which improvements in energy efficiency affect bank's profitability. First, an improvement in energy efficiency of the financial sector reduces its operational costs and makes resources available for their credit business. The growth in credit supply induced by an improvement in energy efficiency leads to banks' higher profitability. As noted by Mlachila et al. (2013), the banking systems in Sub-Saharan Africa (SSA) operate at high costs and account for a significant share of financial sector assets and activities. Second, the emissionreducing effect of energy efficiency can have positive implications on labor productivity and, hence, profit. Third, improvements in energy efficiency in the industrial and residential sectors (i.e., non-financial sectors) of the economy reduce energy costs by cutting down their dependence on other captive expensive energy sources (Adom et al. 2018). Consequently, this can reduce the risk of loan default and banks' credit risk. Thus, by helping to control financial risks, such as credit risk (Kou et al. 2014), energy efficiency improvements can help minimize loan default and improve profitability of the bank, all other things being equal. As noted by Wang et al. (2020), loan default impacts bank's profitability through the loss of service fees and damages its reputation in quality of service on credit rating and setting of interest rates.

The empirical and theoretical literature have identified several factors (i.e., economic, institution, and bank characteristics) that affect the performance of the financial sector (see Seemule et al. 2017; Bougatef 2017; Obamuyi 2013; Olson and Zoubi 2011; Karim et al. 2010; Flamini et al. 2009, inter alia). However, potential effects of energy indices on the

\footnotetext{
${ }^{1}$ In 2014, the sub-region recorded the lowest financial depth of $24.4 \%$ compared with $134 \%$ for the Organization for Economic Co-operation and Development (OECD) countries and 45.5\% for Latin America and the Caribbean (Nyantakyi and Sy 2015). In the same year, the sub-region recorded the lowest level of financial intermediation of approximately 35.3\% compared with $73.4 \%$ for North Africa, $114.4 \%$ for highincome OECD countries, and 54\% for Latin America and the Caribbean (Nyantakyi and Sy 2015). In addition, the degree of financial penetration in SSA was low; only $21 \%$ of the adult population had a bank account compared with 34\% in America and the Caribbean and 90\% in OECD countries (Nyantakyi and Sy 2015). In the period 2012-2013, NPLs as a percent of loans averaged 7.8\% and 6.9\% for SSA middle-income and lowincome countries, respectively (European Investment Bank 2015).
} 
performance of the financial sector, especially in Africa, are not sufficiently explained. The link between financial and energy sectors have been acknowledged in the literature. According to the World Bank Enterprise survey (2013), approximately 40\% of firms in 61 developing countries in SSA, North America, Middle East, and South Asia own generators despite being connected to the national grid. As a result, these firms face rising operational costs, which negatively affect their performance and ability to pay loans (Adom et al. 2019a, b; Nikolaidou and Vogiazas 2017). Kaufmann et al. (2011) found that the rise in energy costs constrains households' budgets and raises the mortgage delinquency rates in the U.S. A recent Bank of Ghana Report (2016) showed that the insecurity in energy supply and high energy costs contributed significantly to the rise of non-performing loans (NPLs) in Ghana.

In the empirical literature, few studies have investigated the link between energy indices and profitability. They include Adom et al. (2019a, b), Kaufmann et al. (2011), Carr and Beese (2008), Fan et al. (2017), Bunse et al. (2011), Yang (2010), and Subrahmanya (2006a, b). Except for Adom's (Adom et al. 2019a, b) study that examined the effect of energy intensity on bank-based measures of financial development in Ghana, remaining studies looked at the effect of energy efficiency on industries' profits. Furthermore, none of the current studies provided a cross-country analysis of this issue. Finally, another important gap in the literature is the failure to control for the political environment.

At the national level, drafting, implementing, and enforcing an energy efficiency policy is a politically driven decision. Some studies have examined how political institutions affect energy efficiency. Although Ramos-Real et al. (2015) found positive effect of democratic regime on energy efficiency, Adom (2018) came to opposite conclusion. Adom (2018) cited factors, such as the lack of coordination, regulatory failures, high corruption, and rentseeking behavior to explain his result. The existence of rent-seeking and corruption can prevent the adoption of clean energy and reduce energy efficiency enhancement (Gennaioli and Tavoni, 2011; Fredriksson et al., 2004). In addition, corruption can induce lobbying and restrict energy efficiency stringency (Fredriksson et al., 2004). Amuakwa-Mensah et al. (2018) have also argued that the winner-take-all feature that characterizes most democratic governance in SSA has the tendency to create strong interest or pressure groups. ${ }^{2}$ Strong interest groups, emerging from ruling parties, can create a 'grandfathering system' as a compensatory scheme to reward their loyalty (Amuakwa-Mensah et al. 2018). For this group, there is a high possibility not to adhere strictly to energy efficiency regulations and still not be punished (for fear of payback during the election period). Conversely, pressure groups from the opposition political party and civil society groups can boycott or resist government policies promoting energy efficiency if they have welfare implications and sometimes for purposes of pursuing a political agenda to make the ruling political party unpopular. ${ }^{3}$

\footnotetext{
${ }^{2}$ In SSA, there has been the emergence of strong interest and pressure groups throughout the region after the shift to a democratic regime (Abimbola 2002).

${ }^{3}$ The implementation of the refrigerator efficiency project by the Energy Commission of Ghana, which led to the institution of two legislative instruments - Energy Efficiency of 2008 and Energy Efficiency Standards and Labelling (household refrigerating appliances) of 2009, - to abolish the importation of second hand refrigerators received fierce resistance from the second-hand refrigerator market (Agyarko 2016). In South Africa, the implementation of the government's energy efficiency programmes received fierce resistance for various reasons, such as attitude (i.e., I know my business best and do not need anyone to tell me how to run my business), resistance to change (i.e., why move away from the usual known, tried, and tested ways to an unknown way of doing things), lack of capital to support the huge capital outlay of energy efficiency technologies, cheap energy (i.e., the cost of energy in total input costs is minimal), and the uncertainty about the payback period of energy efficiency investments (Fawkes 2005; Bennett 2001). Recorded cases of public resistance to government programmes in the energy sector in SSA are on the widespread.
} 
Given that there is a correlation between energy efficiency and political institutional regime, a model of financialization and energy efficiency that fails to account for the role of political institutions would create an identification problem. This study makes the following contributions to the literature. To the best of our knowledge, we provide in this study the first cross-country evidence of the effect of energy efficiency on financial (bank) performance. To address the potential endogeneity problem, we condition the effect of energy efficiency on the political regime type. By this approach, we condition out the effects of political institutional type and improve the identification of the energy efficiency variable.

This paper develops as follows. First, we review the empirical literature. Second, we provide a context analysis of the financial sector in Africa. Third, we present the empirical model used in the study, econometric technique, and data. Fourth, we discuss the results of the study. Finally, we conclude with final remarks and policy implications.

\section{Literature review}

Theoretically, banks' performance has been modeled as a function of both internal and external factors. Internal factors are defined as factors under the control of banks (i.e., risk, bank size, capitalization, operational efficiency, portfolio composition, ownership structure, bank leverage, etc.). Conversely, external factors are considered as those factors outside of the banks' control (i.e., money supply, inflation, and growth in the gross domestic product). Based on this, empirical studies have investigated the roles of different internal and external factors in banks' performance, but neither internal nor external factors have emerged to dominate the other in these studies.

\section{Bank profitability, internal, and external factors}

In Africa, Flamini et al. (2009) investigated the performance of 41 SSA commercial banks covering the period 1998-2006. They revealed that macroeconomic factors (i.e., GDP growth and inflation) explain profitability in the region. Likewise, bank-specific factors, such as bank size, diversification, and private ownership, explain bank profitability, but not its credit risk. Furthermore, Karim et al. (2010) investigated the drivers of profitability of African Islamic banks. In congruence to Flamini et al. (2009), their study revealed the importance of internal and external factors in explaining banks' performance. Specific results showed that bank capital, market concentration, and size had positive impact on banks' profitability, whereas the impact of credit risk and operating inefficiency was negative. Both economic growth and inflation have positive effects on profitability. In contrast, by examining profitability drivers of 44 Islamic banks from Asia and Africa, Chowdhury and Rasid (2015) found no significant role for liquidity, credit risk, and economic growth. However, they established a positive role for equity finance and inflation and a negative role for operational inefficiency. Contrary to the abovementioned conclusions, Olson and Zoubi (2011), who examined the case of MENA countries, found that cost efficiency has little impact on profitability.

Elsewhere in Asia and the Gulf Cooperation Council (GCC), Tan and Floros (2012) studied 101 banks in the Chinese economy. They revealed that profitability is positively related to banking sector development, stock market development, cost efficiency, and inflation. Sufian (2012) investigated the drivers of bank performance for 77 commercial 
banks in Bangladeshi, Sri Lanka, and Pakistan, and found that liquidity, non-interest income, credit risk, and capitalization affect profitability positively, but cost reduces profit. Economic growth has a significant positive effect, but inflation has no effect. Siddik et al. (2016) studied banks in Bangladesh. Their result confirmed that capitalization increases profitability, whereas banks' size decreases it. The significance of macroeconomic factors, however, could not be established.

Investigating the drivers of bank performance in GCC countries, Zeitun (2012) found important roles for both internal and external factors. Specifically, for the former, the study revealed that both the bank's size and operational efficiency drive performance upwards. For the latter, although economic growth exerts a positive effect on bank's performance, inflation exerts a negative effect. Chowdhury et al. (2016) also investigated the roles of internal and external factors in explaining the performance of Islamic banks. Their findings show that the equity to asset ratio, bank size, and capital ratios positively influence profitability, whereas the effect of the risk, operational inefficiency, and inflation is negative. In their analysis on the performance drivers of Islamic banks, Nawaz and Haniffa (2017) showed that whereas large size significantly drive performance upwards, higher risk harms the performance of the banks. Asma et al. (2011) found that, among the set of internal factors, only size matters in explaining bank performance. In contrast, Izhar and Asutay (2007) found no significant role for internal factors in explaining banks' performance.

In Europe, Kosmidou (2008) studied the case of Greek banks during the EU financial integration. Their result showed that large size, higher capitalization, and lower costs drove the performance of Greek banks upwards, as well as the GDP growth. However, they also found that inflation negatively affected banks' profitability and this finding contradicts the findings of Athanasoglou et al. (2006). Kosmidou et al. (2008), who studied commercial banks in the UK, found that some internal factors (i.e., operational efficiency and capitalization) and external factors (i.e., GDP growth and inflation) have positive effects on profitability. However, they also noted that the bank's size negatively affects its profitability. By examining the case of 143 banks from Central and Eastern Europe, Capraru and Ihnatov (2014) found that managerial efficiency, capital adequacy, credit risk, and inflation drive profitability. Furthermore, Petria et al. (2015) revealed that, for EU 27 banking system, credit risk, liquidity risk, management efficiency, market concentration, economic growth, and diversification significantly drive banks' profit.

Other studies focused on specific countries. Obamuyi (2013) studied the drivers of commercial banks' performance in Nigeria and the results confirmed the importance of both internal and external factors. Specific results revealed that improved macroeconomic conditions, operational efficiency, and higher capitalization impact profitability positively, but the size of the banks drag performance down, which contradicts the findings of Karim et al. (2010) and Flamini et al. (2009). Seemule et al. (2017) studied the case of Botswana's commercial banks. Their results confirmed the important role of internal and external factors in explaining banks' performance. Specifically, their results showed that operational efficiency, size, capital adequacy, and asset quality positively influence profitability, whereas the effect of GDP growth and money supply is negative. No statistical evidence was established for inflation, albeit the effect is positive. Bougatef (2017) examined the performance of banks while considering the importance of the corruption and showed that corruption and market capitalization increase profitability, whereas a poor asset quality reduces it. 


\section{Financial performance and energy indices}

An important limitation of the above studies, especially from the perspective of Africa, is the exclusion of a potentially important variable, that is, energy efficiency. In the econometric sense, this could cause a potential omission variable bias problem. Few studies have attempted to control for the important role of energy efficiency, largely focusing on Asian countries. Subrahmanya (2006a) used micro-level data to investigate energy efficiency and economic performance in Indian brick and foundry firms. According to the results, firms with lower energy intensity levels recorded higher returns than their high energy intensity level counterparts. Also, Subrahmanya (2006b) used micro-level data to investigate the relationship between labor productivity, energy intensity, and economic performance for small brick enterprises in India. The results showed inverse relationship between energy intensity and economic performance of these enterprises.

In China, Yang (2010) investigated the returns on energy efficiency investment for large shoe-making enterprises, showing that an investment of US\$ 1.9 million in energyefficient technologies increases the net present value of the investment by US\$ 9.8 million. In a related study, Bunse et al. (2011) found that improving energy efficiency increases the net present value and reduces the payback period of the investment. Consequently, production levels and firm performance improve. Fan et al. (2017) investigated the effect of energy efficiency improvements on firm performance in China. In all cases, energy intensity has a significant negative effect on firm performance, which implies that improving energy efficiency can trigger higher firm performance in China.

The above studies looked at the production sectors, without considering the effect of energy efficiency on banking sector profitability. One notable exception is the study by Adom et al. (2019a, b). Adom et al. (2019a, b) examined the effects of energy indices on bankbased measures of development in Ghana, using time series data. The author found that higher energy intensity reduces financial development. However, his study did not consider the moderating effect of political institutional regime types. Thus, an important area of improvement in the current literature is to explicitly model endogeneity in energy efficiency. As discussed earlier in this paper, the political institutional regime type moderates the effects of energy efficiency on banking sector performance. In this paper, we controlled for the effects of political institutional type as well as the interaction of political institutional type and energy efficiency to condition out the effects of political institutional type from the model. This provides the advantage of improving energy efficiency identification. Hence, we hypothesize that improvements in energy efficiency drive banks' profitability more in economies with centralization of power than in those with decentralization of power.

\section{Method and data}

This section describes the empirical model used in this study, as well as the data. In addition, we perform a preliminary test of the data in terms of unit root with and without cross-sectional dependence.

\section{Empirical model}

The empirical approach in this study follows the approaches adopted in the studies of Fan et al. (2017), Nawaz and Haniffa (2017), and Tan and Floros (2012). However, it 
differs in the inclusion of an indicator for energy efficiency (i.e., energy intensity), which is motivated by studies, such as Adom et al. (2019a, b), Fan et al. (2017), Kaufmann et al. (2011), Carr and Beese (2008), and Subrahmanya 2006a Banking performance (BP) is expressed as a function of the lag in bank performance, bank size (SIZE), credit growth (CreditGrowth), risk (RISK), managerial inefficiency (MIE), financial fragility (FG), energy efficiency indicator $(E E)$, and other controls $(X)$ in Eq. 1, where $\eta$ represents unobserved country-specific effects, and $t$ is the time effect. Bank credit growth is captured as the annual change in domestic credit to the private sector. As there is a time lag between giving a loan and reaping the benefits, we include one-year time lag for the growth in bank credit. To measure credit risk, we used asset quality. Managerial inefficiency is measured as the ratio of cost to revenue whereas financial fragility is measured using the $\mathrm{z}$-score (the higher the $\mathrm{z}$-score, the more sound is the financial system and vice versa). Furthermore, the return on assets (ROA) is used as an indicator of commercial banks' performance. This indicator gives the investor a better idea of the bank's efficiency in converting its assets into net income. In contrast to Fan et al. (2017), Seemule et al. (2017), Siddik et al. (2016), and Obamuyi (2013) — that used total assets, average assets, and total sales as measures of the bank's size-we use market capitalization to indicate the size of the firm, as it has been acknowledged in the finance literature to be a better measure of size than other traditional measures. For example, measures such as total assets and average assets ignore liabilities, asset's ability to generate profit, and intangible assets. In contrast, because market capitalization relates to the stock price, it considers other factors that do not appear in the balance sheet, such as market share, psychology of the market, management expertise, company's reputation, growth prospects, and unlisted intangible assets. Equation 1 is the baseline model:

$$
\begin{aligned}
\mathrm{BP}_{i t}=\alpha & +\beta_{0} B P_{i, t-1}+\beta_{1} \text { SIZE }_{i t}+\beta_{2} \text { CreditGrowth }_{i, t-1}+\beta_{3} \text { RISK }_{i t}+\beta_{4} F_{i t} \\
& +\beta_{5} M I E_{i t}+\beta_{6} E E_{i t}+\beta_{7} X_{i t}+\eta_{i}+t_{i t}+\varepsilon_{i t}
\end{aligned}
$$

The bank-based indicators are considered as the internal factors that drive a commercial bank's performance. For the external factors, this study considers the effects of economic growth (measured as growth in real GDP), inflation (measured as the growth/changes in the implicit GDP deflator), and the type of a political regime (measured using the polity2 measure of democracy). The energy efficiency indicator can be considered as an internal as well as external factor. The share of the service sector value-added as a percent of GDP $(\mathrm{SSH})$ is used to capture the changes in economic structure. In addition, the inclusion of inflation is expected to deal with issues pertaining to price regimes.

Furthermore, energy efficiency is measured using the energy intensity indicator. Adom et al. (2018) found a negative correlation between energy efficiency and energy intensity in Africa. In other words, lowering energy intensity promotes energy efficiency. One main drawback of using the energy intensity indicator is that changes in the measure could suggest structural changes in output/production in the economy and not changing technology that leads to improvements in energy efficiency (Amuakwa-Mensah et al. 2018; Adom et al. 2018). Moreover, the pricing regime could also affect energy intensity in a manner that does not suggest an improvement in energy efficiency. Despite these drawbacks, the energy intensity indicator remains the widely used indicator of economic-wide energy efficiency 
because of the ease in interpretation and computation (Zhang and Broadstock, 2016). To deal with the problem of energy intensity measurement, this study augments the empirical model to include a measure of structural change in output as an additional external factor and inflation to capture the price regime effects.

An alternative approach is to estimate total factor productivity and use it as a measure of energy efficiency; however, we do not use this approach for the following reasons. First, total factor productivity suffers from the same problem as energy intensity as several factors that affect total factor productivity may have nothing in common with technological improvements. Moreover, the measure is not specific to energy as a resource, but covers a wide range of other non-energy resources. Lastly, such a two-stage approach can be problematic as biases encountered during the estimation of total factor productivity may enter into the second stage of analysis, and this could aggravate the bias in our profitability model. As a further robustness check, this study used petroleum energy intensity to proxy energy efficiency. Petroleum energy correlates well with the other energy sectors and all sectors in the economy. Therefore, achieving efficiency in its use would produce wider economic impacts and, hence, promote the performance of commercial banks.

The political regime is captured using the polity 2 indicator. As there is an important correlation between energy efficiency and political regime type, we include the interactions of the energy efficiency indicator and political regime in Eq. 2. The advantage of introducing this indirect effect is that it enables the derivation of the country-specific marginal effects of energy efficiency on bank performance, given the political environment. This helps addressing the potential heterogeneity in energy efficiency effects on bank performance. Moreover, it addresses omission variable bias in the model. Equation 3 is used to evaluate the marginal effects of energy efficiency on bank performance.

The statistical significance of $\beta_{11}$ suggests an important interaction between energy efficiency enhancement and the political regime. Thus, these variables do not follow parallel paths. If $\beta_{6}$ and $\beta_{11}$ are both significantly negative, the political regime reinforces the profitability-induced effect of energy efficiency enhancement. However, when the latter parameter is positive, but the former parameter is negative, the political regime distorts the profitability-induced effect of energy efficiency enhancement. Furthermore, $\beta_{6}$ ' captures the direct effect of the energy efficiency indicator on commercial banks' profitability given that the political institution variable is equal to zero. This makes sense as zero in the political institution data corresponds to strong autocratic regime. Thus, $\beta_{11}$ ' measures the differentiating effect of energy intensity on commercial banks' performance between strong autocratic regime and democratic regime. We used the nonlinear function in STATA to compute the total effect of energy intensity on commercial banks' profitability, which is evaluated at the mean.

$$
\begin{aligned}
B P_{i t}=\alpha & +\beta_{0} B P_{i, t-1}+\beta_{1} \text { SIZE }_{i t}+\beta_{2} \text { CreditGrowth }_{i, t-1}+\beta_{3} \text { RISK }_{i t}+\beta_{4} F G_{i t} \\
& +\beta_{5} \text { MIE }_{i t}+\beta_{6} E E_{i t}+\beta_{7} \text { GDPgrowth }_{i t}+\beta_{8} \text { Infl }_{i t}+\beta_{9} \text { SSH }_{i t}+\beta_{10} \text { Polity }_{i t} \\
& +\beta_{11} E E_{i t} * \text { Polity }_{i t}+\eta_{i}+t_{i t}+\varepsilon_{i t}
\end{aligned}
$$




$$
\frac{\partial B P_{i t}}{\partial E E_{i t}}=\beta_{6}+\beta_{11} \text { Polity } 2_{i t}
$$

\section{Estimation technique: two-stage system generalized method of moments (GMM)}

To identify the coefficients in Eqs. 1 and 2, the two-stage system GMM, which addresses endogeneity, serial correlation, and heteroscedasticity, was used to estimate both Equations. As Eqs. 1 and 2 may be vulnerable to econometric issues of endogeneity and heteroscedasticity, the application of the ordinary least squares estimator will not produce consistent estimates. First, given first-order autocorrelated errors, the lagged dependent variable will be correlated with the error terms in Eqs. 1 and 2 causing model identification problem. Second, the unobserved country-specific effects will also be correlated with the lagged dependent variable. Third, the set of regressors in the model could be endogenous. To address these issues, Arellano and Bond (1991) proposed the one-step GMM difference method, which introduces a set of internal instruments as the solution. However, Blundell and Bond (1998) noted that the one-step GMM difference approach suffers from bias, and that the estimates are imprecise. This is because when the lag dependent variable and the set of explanatory variables exhibit inertia, the lag level variables become poor instruments (Amuakwa-Mensah et al. 2018).

The two-step system GMM rather solves this bias and imprecision by, first, assuming independent and homoscedastic error terms and, then, using the first-step residuals to construct consistent variance and covariance matrices in the second stage (AmuakwaMensah et al. 2018). However, this approach also converges slowly to its asymptotic distribution, which in finite sample cases makes the standard errors downward bias (Amuakwa-Mensah et al. 2018; Amuakwa-Mensah and Adom 2017). Windmeijer (2005), in this case, suggests using multiple lags as instruments; however, this could also create over-identification problem. This study minimizes the number of lags and then uses the Sargan test to check for instrument validity. To test for serial correlation, in this study, we hypothesize serial correlation at the first-order, but not at the secondorder. In addition, we applied the Pesaran (2004, 2015) cross-sectional dependence test on the residuals from the system GMM estimator. As acknowledged by De Hoyos \& Sarafidis (2006), panel data models can exhibit high cross-sectional dependence caused by the presence of common shocks, spatial dependence, unobserved components of the error term, and idiosyncratic pairwise dependence in the disturbances. Additionally, following the studies of Adom et al. (2019b), Sadorsky (2013) and Amuakwa-Mensah et al. (2018), we test for the stationarity of the system GMM residuals.

\section{Data}

The study uses panel data covering 43 SSA countries for the period 1998-2012.4 Whereas data on banking performance (return on asset), bank size (market capitalization), financial fragility (z-score), risk (asset quality) and managerial inefficiency (cost to revenue ratio) are sourced from the work of Andrianova et al. (2015), data on the macroeconomic variables (i.e., economic growth, inflation, and the service sector share in total output), energy intensity, and growth in domestic credit to the

${ }^{4}$ This obviously poses a data limitation problem. However, the most recent data source according to the data compiled by Andrianova et al. (2015) ends in 2012. 
private sector by banks are from the World Bank's World Development Indicator (WDI). The political regime proxy (i.e., polity2) was sourced from the Polity IV Project. ${ }^{5}$ Table 1 shows the definitions of the variables used in the study with their respective descriptive statistics. Table 2 shows the Pesaran's (2007) CIPS unit root test. Among the bank-based variables, only asset quality exhibit cross-sectional dependence and stationarity in levels. Therefore, the first generation panel-based unit root tests can be applied to these bank-based variables. As shown in Table 3, these bank-based variables that do not exhibit cross-sectional dependence are stationary in levels. Among the external factors, including the indicator of energy efficiency, there is the evidence of cross-sectional dependence and stationarity in levels. Thus, for these variables, the Pesaran's (2007) cross-sectional unit root test was used.

\section{Results and discussion}

For the purposes of this study, we concentrate largely on the conditional effects of energy intensity on commercial banks' profitability. We defer the explanation of the controls to section 4.4.

\section{Commercial banks' performance - energy efficiency Nexus}

Table 4 shows the estimated impact of energy intensity on commercial banks' performance. Columns 1 and 2 contain the baseline results and the effect of energy intensity on commercial banks' profitability conditioned on the political regime, respectively. In these two columns, the aggregate energy intensity indicator is used as the measure of energy efficiency. All the models passed the serial correlation test and the Sargan test of valid instruments. ${ }^{6}$ For the Pesaran's $(2004,2015)$ cross-sectional dependence test of the residuals, the null hypothesis of cross-sectional independence cannot be rejected both for the baseline model and the general model. The unit root tests of the GMM residuals are also stationary in levels for all the models, as indicated by the $p$-value in the bottom of the table. The discussion of the results hereafter is based on column 2, which presents the data of the general model.

The direct effect of energy intensity on commercial banks' profit is negative and statistically significant at $1 \%$ significance level. According to the estimated direct effect, a $10 \%$ increase in energy intensity (i.e., decrease in energy efficiency) would cause a decline in commercial banks' profitability by $10.38 \%$. The negative effect implies that a reduction in energy intensity, which indicates a rise in energy efficiency, would significantly increase the profitability of commercial banks in SSA. These findings are very consistent with the findings of Adom et al. (2019a, b), Fan et al. (2017) and Subrahmanya (2006b), who all found that improvement in energy efficiency directly leads to higher firm/bank/financial sector performance. Improvements in energy efficiency reduce the energy budget burden of energy consumers and, consequently, release extra resources for households and enterprises to meet other expenditures, such as paying the loans. By implication, energy efficiency improvements have the tendency to reduce the risk of loan default on the part of borrowers and thereby minimize the size of nonperforming loans on the part of the banking sector. For the banking sector, improvements in energy efficiency, which enhance energy supply security, would reduce the

\footnotetext{
${ }^{5} \mathrm{http}: / /$ www.systemicpeace.org/polity/polity4.htm

${ }^{6}$ The Hansen test of instrument validity is not reported here as STATA command does not have the Hansen test for xtdpdsys as a post-estimation code.
} 
Table 1 Descriptive statistics

\begin{tabular}{|c|c|c|c|c|c|c|c|c|c|}
\hline \multirow[t]{2}{*}{ VARIABLES } & \multirow[t]{2}{*}{ Proxy } & \multirow[t]{2}{*}{ Definition } & \multirow{2}{*}{$\begin{array}{l}(1) \\
N\end{array}$} & \multirow{2}{*}{$\begin{array}{l}(2) \\
\text { mean }\end{array}$} & \multirow{2}{*}{$\begin{array}{l}(3) \\
\text { sd }\end{array}$} & \multirow{2}{*}{$\begin{array}{l}(4) \\
\min \end{array}$} & \multirow{2}{*}{$\begin{array}{l}\text { (5) } \\
\max \end{array}$} & \multirow{2}{*}{$\begin{array}{l}\text { (6) } \\
\text { skewness }\end{array}$} & \multirow{2}{*}{$\begin{array}{l}\text { (7) } \\
\text { kurtosis }\end{array}$} \\
\hline & & & & & & & & & \\
\hline $\begin{array}{l}\text { Bank } \\
\text { performance }\end{array}$ & $\begin{array}{l}\text { Return on } \\
\text { asset (ROA) }\end{array}$ & $\begin{array}{l}\text { Net Income / Total } \\
\text { Assets }\end{array}$ & 593 & 2.287 & 2.381 & -10.57 & 21.79 & 1.414 & 18.42 \\
\hline Bank size & $\begin{array}{l}\text { Market } \\
\text { Capitalization }\end{array}$ & Equity / Total Assets & 596 & 11.33 & 6.090 & -11.74 & 69.28 & 3.246 & 24.64 \\
\hline Risk & Asset quality & $\begin{array}{l}\text { Impaired Loan/Gross } \\
\text { Loan }\end{array}$ & 435 & 9.119 & 8.105 & 0.0300 & 55.47 & 1.918 & 7.905 \\
\hline $\begin{array}{l}\text { Managerial } \\
\text { Ineffic. }\end{array}$ & $\begin{array}{l}\text { Ratio of cost } \\
\text { to revenue }\end{array}$ & Cost / Revenue & 580 & 59.02 & 21.18 & 3.810 & 230.6 & 1.534 & 12.81 \\
\hline $\begin{array}{l}\text { Financial } \\
\text { fragility }\end{array}$ & Z-score & $Z_{i t}=\frac{R O A_{i t}+\text { equity } / \text { assets } s_{i t}}{\sigma R O A_{i}}$ & 593 & 13.92 & 11.11 & -7.881 & 73.89 & 2.086 & 9.360 \\
\hline Bank growth & $\begin{array}{l}\text { Lag of growth } \\
\text { private sector } b\end{array}$ & $\begin{array}{l}\text { in Domestic credit to } \\
\text { yy bank (\% of GDP) }\end{array}$ & 583 & 0.0423 & 0.258 & -2.417 & 2.633 & 0.0984 & 36.16 \\
\hline GDP growth & Gross domestic & product growth rate & 658 & 4.843 & 6.050 & -30.15 & 63.38 & 1.680 & 22.71 \\
\hline Inflation rate & Inflation rate & & 623 & 53.84 & 979.2 & -35.84 & 24,411 & 24.76 & 616.4 \\
\hline InServicevalue & $\begin{array}{l}\text { Natural log of } s \\
\text { of GDP) }\end{array}$ & ervice value added (\% & 563 & 3.796 & 0.314 & 2.555 & 4.516 & -0.980 & 4.641 \\
\hline Institution $^{a}$ & Polity2 & $\begin{array}{l}\text { Polity score is } \\
\text { computed by } \\
\text { subtracting the p_ } \\
\text { autocracy score from } \\
\text { the p_democracy } \\
\text { score }\end{array}$ & 629 & 0.573 & 0.265 & 0 & 1 & -0.0766 & 1.716 \\
\hline Lnei & $\begin{array}{l}\text { Natural log of } \\
\text { energy } \\
\text { intensity }\end{array}$ & $\begin{array}{l}\text { Energy intensity level } \\
\text { of primary energy }\end{array}$ & 644 & 1.943 & 0.621 & 0.400 & 3.525 & 0.319 & 2.692 \\
\hline Lneipet & $\begin{array}{l}\text { Natural log of } \\
\text { petroleum } \\
\text { intensity }\end{array}$ & $\begin{array}{l}\text { Ratio of Total } \\
\text { Petroleum } \\
\text { Consumption to GDP }\end{array}$ & 659 & -13.07 & 0.697 & -15.85 & -11.01 & -0.650 & 5.188 \\
\hline Lneielec & $\begin{array}{l}\text { Natural log of } \\
\text { electricity } \\
\text { intensity }\end{array}$ & $\begin{array}{l}\text { Ratio of Total } \\
\text { Electricity Net } \\
\text { Consumption to GDP }\end{array}$ & 659 & -15.46 & 0.919 & -18.55 & -13.21 & -0.517 & 4.520 \\
\hline
\end{tabular}

NB: $\sigma R O A_{i}$ is a country-specific standard deviation of the national average value of $R O A\left(R O A_{j t}\right)$ over time

apolity 2 scale ranges from +10 (strongly democratic) to -10 (strongly autocratic), we however transformed the variable to range from 0 (strongly autocratic) to 1 (strongly democratic) for easy interpretation

Table 2 Cross-sectional dependence test

\begin{tabular}{lllll}
\hline Variable & CD-test & $\boldsymbol{p}$-value & Correlation( $(\boldsymbol{\rho})$ & abs( $)$ \\
\hline Return on asset & 0.46 & 0.647 & 0.01 & 0.35 \\
Managerial inefficiency & 1.15 & 0.252 & 0.01 & 0.37 \\
Z-score & -1.16 & 0.110 & -0.01 & 0.36 \\
Market capitalization & -0.72 & 0.472 & 0.00 & 0.37 \\
Asset quality & 3.26 & 0.001 & 0.03 & 0.33 \\
Lnei & 20.42 & 0.000 & 0.17 & 0.54 \\
Polity2 & 11.76 & 0.000 & 0.09 & 0.24 \\
GDP growth & 7.67 & 0.000 & 0.06 & 0.23 \\
InServicevalue & 7.23 & 0.000 & 0.06 & 0.32 \\
Inflation & 14.15 & 0.000 & 0.12 & 0.29 \\
Lneipet & 7.09 & 0.000 & 0.06 & 0.44 \\
Lneielec & 10.64 & 0.000 & 0.09 & 0.46 \\
\hline
\end{tabular}

Under the null hypothesis of cross-section independence, $\mathrm{CD} \sim \mathrm{N}(0,1) . P$-values close to zero indicate data are correlated across panel groups 
Table 3 Unit root test

\begin{tabular}{|c|c|c|c|c|}
\hline & ADF & & Philip-Perron & \\
\hline & Inverse logit & Modified inv. chi-squared & Inverse logit & Modified inv. chi-squared \\
\hline $\mathrm{ROA}$ & $-13.38^{* * *}$ & $17.95^{* * *}$ & $-5.91^{* * *}$ & $6.75^{* * *}$ \\
\hline Lag Credt growth & $-22.26^{* * *}$ & $33.78^{* * *}$ & $-21.9^{* * *}$ & $33.53^{* * *}$ \\
\hline Risk & $-8.96^{* * *}$ & $11.23^{* * *}$ & $-1.54^{*}$ & $1.96^{* *}$ \\
\hline Size & $-11.89^{* * *}$ & $15.96^{* * *}$ & $-6.56^{* * *}$ & $10.52^{* * *}$ \\
\hline Managerial inefficiency & $-12.66^{* * *}$ & $16.93^{* * *}$ & $-5.19^{* * *}$ & $6.59^{* * *}$ \\
\hline Financial soundness & $-12.45^{* * *}$ & $16.81^{* * *}$ & $-7.65^{* * *}$ & $12.17^{* * *}$ \\
\hline Lnei & $-7.46^{* * *}$ & $9.37^{* * *}$ & 1.94 & 0.86 \\
\hline Lneipet & $-9.32^{* * *}$ & $11.60^{* * *}$ & -0.20 & $1.47^{*}$ \\
\hline Lneielec & $-13.15^{* * *}$ & $19.21^{* * *}$ & $-7.89^{* * *}$ & $15.11^{* * *}$ \\
\hline GDP growth & $-22.69^{* * *}$ & $34.52^{* * *}$ & $-21.92^{* * *}$ & $33.84^{* * *}$ \\
\hline Inflation & $-18.30^{* * *}$ & $28.41^{* * *}$ & $-15.62^{* * *}$ & $23.37^{* * *}$ \\
\hline InServicevalue & $-10.75^{* * *}$ & $13.87^{* * *}$ & $-2.68^{* * *}$ & $3.49^{* * *}$ \\
\hline Polity2 & $-9.98^{* * *}$ & $13.11^{* * *}$ & $-3.95^{* * *}$ & $2.996^{* * *}$ \\
\hline Fin.Soundness*Inei & $-12.42^{* * *}$ & $16.59^{* * *}$ & $-7.23^{* * *}$ & $10.81^{* * *}$ \\
\hline Polity2*Inei & $-12.53^{* * *}$ & $17.01^{* * *}$ & $-8.21^{* * *}$ & $13.16^{* * *}$ \\
\hline
\end{tabular}

banks' dependence on other captive plants that run on expensive fuels for energy. The improved cost profile of the banks can impact positively on their cost competitiveness, capital market efficiency, and minimize both systemic and market risks of the commercial banks. Finally, the emission-reducing effects of energy efficiency improvements can improve environmental quality and create a conducive work environment that will promote labor or workers' productivity. Zivin and Neidell (2012) and Neidell (2017) found that an improvement in environmental quality (i.e., reduction in pollution) improves worker productivity.

The direct negative effect of energy intensity on commercial banks' profitability is conditioned on a zero polity2, which corresponds to strong autocratic political regime. This suggests that the profitability-induced effect of energy efficiency is more enhanced in an autocratic political regime. Especially in the context of Africa, energy efficiency programs are still developing and the importance of energy efficiency is not widely appreciated. Consequently, any attempts to introduce energy efficiency measures are likely to be opposed by many in the region, especially when the real benefits of energy efficiency have not been well documented. Therefore, it would require a government system that is able to take strong decisions in the fast implementation of energy efficiency policies without opposition and the punitive measures to punish defaulters of the policy. The centralization of power under autocratic political regime provides this environment.

However, the indirect effect of energy intensity conditioned on democratic political regime is significantly positive, which suggests that energy efficiency improvements in this political regime are less likely to translate into higher bank profitability. Decentralization of power that characterizes democratic governance systems breeds group polarization (i.e., strong interest groups or pressure groups from the opposition political party and civil society groups), which could delay the implementation or 
Table 4 Estimation Results

\begin{tabular}{|c|c|c|c|c|c|c|}
\hline & \multicolumn{2}{|c|}{ Aggregate energy intensity } & \multicolumn{3}{|c|}{ Reverse Causality \& sensitivity analysis } & \multirow[b]{2}{*}{ (6) } \\
\hline & $(1)$ & $(2)$ & (3) & (4) & (5) & \\
\hline VARIABLES & Uncond. & El\&Polity2 & El\&Polity2 & El\&Polity2 & El\&Polity2 & El\&Polity2 \\
\hline \multirow[t]{2}{*}{ L.ROA } & $0.122^{* * *}$ & $0.159^{* * *}$ & $0.187^{* * *}$ & $0.161^{* * *}$ & $0.0526^{* *}$ & $0.0509^{* *}$ \\
\hline & $(0.0254)$ & $(0.0334)$ & $(0.0246)$ & $(0.0287)$ & $(0.0210)$ & $(0.0224)$ \\
\hline \multirow[t]{2}{*}{ CreditGrowth (lag) } & $1.567^{* * *}$ & $1.699^{* * *}$ & $1.866^{* * *}$ & $1.577^{* * *}$ & $1.837^{* * *}$ & $1.842^{* * *}$ \\
\hline & $(0.185)$ & $(0.250)$ & $(0.244)$ & $(0.231)$ & $(0.290)$ & $(0.298)$ \\
\hline \multirow[t]{2}{*}{ Size } & $0.146^{* * *}$ & $0.152^{* * *}$ & $0.160^{* * *}$ & $0.187^{* * *}$ & $0.188^{* * *}$ & $0.186^{* * *}$ \\
\hline & $(0.00630)$ & $(0.00880)$ & $(0.0109)$ & $(0.0206)$ & $(0.0165)$ & $(0.0163)$ \\
\hline \multirow[t]{2}{*}{ Risk } & $-0.0179^{* *}$ & -0.0152 & -0.00778 & -0.00365 & $0.0183^{* * *}$ & $0.0189^{* * *}$ \\
\hline & $(0.00804)$ & $(0.00933)$ & $(0.00974)$ & $(0.00586)$ & $(0.00478)$ & $(0.00493)$ \\
\hline \multirow[t]{2}{*}{ MIE } & $-0.0263^{* * *}$ & $-0.0268^{* * *}$ & $-0.0278^{* * *}$ & $-0.0312^{* * *}$ & $-0.0646^{* * *}$ & $-0.0645^{* * *}$ \\
\hline & $(0.00177)$ & $(0.00255)$ & $(0.00286)$ & $(0.00424)$ & $(0.00391)$ & $(0.00384)$ \\
\hline \multirow[t]{2}{*}{ FG } & $0.0718^{* * *}$ & $0.0679 * * *$ & $0.0686^{* * *}$ & $0.0656^{* * *}$ & $0.0512^{* *}$ & $0.0517^{* *}$ \\
\hline & $(0.0133)$ & (0.0109) & $(0.0187)$ & $(0.0212)$ & $(0.0212)$ & $(0.0214)$ \\
\hline \multirow[t]{2}{*}{ GDPgrowth } & $0.108^{* * *}$ & $0.102^{* * *}$ & $0.0829^{* * *}$ & $0.0802^{* * *}$ & 0.00662 & - \\
\hline & $(0.00761)$ & $(0.00874)$ & $(0.0110)$ & $(0.00710)$ & $(0.00837)$ & \\
\hline Infl & $0.0435^{* * *}$ & $0.0446^{* * *}$ & $0.0392^{* * *}$ & $0.0338^{* * *}$ & - & - \\
\hline \multirow[t]{3}{*}{ lag(Inei) } & $(0.00636)$ & $(0.00636)$ & $(0.00545)$ & $(0.00159)$ & $2.340^{* * *}$ & $2.487^{* *}$ \\
\hline & & & $-2.252^{* *}$ & $-1.394^{* *}$ & $(1.162)$ & $(1.093)$ \\
\hline & & & $(0.920)$ & $(0.562)$ & & \\
\hline \multirow[t]{2}{*}{ Lnei } & $1.305^{* * *}$ & $-1.038^{*}$ & - & - & - & - \\
\hline & $(0.176)$ & $(0.580)$ & & & & \\
\hline LnSSH & $4.656^{* * *}$ & $4.250^{* * *}$ & $3.939^{* * *}$ & - & - & - \\
\hline \multirow[t]{3}{*}{ lag(Polity2) } & $(0.711)$ & $(0.754)$ & $(0.722)$ & $-7.711^{* * *}$ & -4.682 & -4.488 \\
\hline & & & $-10.21^{* * *}$ & $(1.837)$ & $(3.443)$ & (3.158) \\
\hline & & & $(2.315)$ & & & \\
\hline \multirow[t]{2}{*}{ Polity2 } & 0.0351 & $-7.372^{* * *}$ & - & - & - & - \\
\hline & $(0.475)$ & $(1.538)$ & & & & \\
\hline Polity2*Inei & - & $3.874^{* * *}$ & - & - & - & - \\
\hline \multirow[t]{2}{*}{$\operatorname{lag}($ polity2)*/ag(Inei) } & & $(0.711)$ & $5.623^{* * *}$ & $4.568^{* * *}$ & 2.123 & 2.046 \\
\hline & & & $(1.268)$ & $(0.906)$ & $(1.690)$ & $(1.525)$ \\
\hline Total effect of Inei & - & $1.183^{* * *}$ & - & - & - & - \\
\hline \multirow[t]{2}{*}{ Total effect of lag(Inei) } & & $(0.215)$ & $0.967^{* * *}$ & $1.221^{* * *}$ & $3.555^{* * *}$ & $3.658^{* * *}$ \\
\hline & & & $(0.241)$ & $(0.232)$ & $(0.246)$ & $(0.261)$ \\
\hline \multirow[t]{2}{*}{ Constant } & $-20.81^{* * *}$ & $-14.77^{* * *}$ & $-11.46^{* * *}$ & $1.697^{*}$ & -1.587 & -1.896 \\
\hline & $(2.601)$ & $(3.226)$ & $(3.832)$ & $(0.968)$ & $(2.406)$ & $(2.324)$ \\
\hline Observations & 329 & 329 & 329 & 374 & 377 & 377 \\
\hline ID & 37 & 37 & 37 & 39 & 40 & 40 \\
\hline Sargan's test (S) & $23.01(25)$ & $22.12(25)$ & 23.71(25) & $31.65(25)$ & $29.65(25)$ & $29.38(25)$ \\
\hline 1st order autocor. & $-1.89^{*}$ & $-1.98^{* *}$ & $-1.91^{*}$ & $-2.08^{* *}$ & $-2.14^{* *}$ & $-2.12^{* *}$ \\
\hline 2nd order autocor. & -0.90 & -0.82 & -0.78 & -1.16 & -1.03 & -1.05 \\
\hline$C D$ & 0.182 & 0.340 & 1.493 & -0.363 & $2.839^{* * *}$ & $3.022^{* * *}$ \\
\hline ADF & 0.000 & 0.000 & 0.000 & 0.000 & 0.000 & 0.000 \\
\hline
\end{tabular}

Standard errors in parentheses $* * * p<0.01, * * p<0.05,{ }^{*} p<0.1$. In the Sargan's test we presented the values and the degree of freedom are in parentheses. We presented the $z$ values for the autocorrelation test. We report $p$-values for the $C D$ and $A D F$ tests 
boycott government policies in energy efficiency. Moreover, democratic governance systems practiced in the region run on the principles of winner-take-all, and this creates a "grandfather system" as a compensatory reward scheme for loyalty to the party. This can create a room for businesses and households who hold a strong allegiance to the ruling political party to default on government programs on energy efficiency stringency without being punished for fear of losing elections in the next election period. As found by Adom (2018), the lack of coordination, high corruption, rent-seeking behavior, and regulatory failures that characterize the democratic governance system make such political institutional type not energy efficiency enhancing.

The above results suggest that the profitability-inducing effect of energy efficiency differs between autocratic and democratic political regime. Figure 1 shows the conditional marginal effects for all the countries. The marginal effect of energy intensity on profitability is negative only in the Gambia, Eritrea, Equatorial Guinea, Sudan, and Swaziland, where power is mostly centralized. This means that, in these economies, improvements in energy efficiency, which translate into lower energy intensity, can translate into higher commercial bank profitability. Contrary, the top most-democratic countries, such as Mauritius, Cape Verde, Botswana, Ghana, South Africa, Lesotho, and Namibia, recorded significantly higher positive marginal effects. By implication, in these economies, improvements in energy efficiency are less likely to translate into higher bank profitability.

\section{Addressing reverse causality}

The development of the financial sector can also trigger changes in energy indices, such as energy consumption (inter alia, Alsaleh and Abdul-Rahim 2019) and energy efficiency (Amuakwa-Mensah et al. 2018; Adom et al. 2019a). These results suggest that

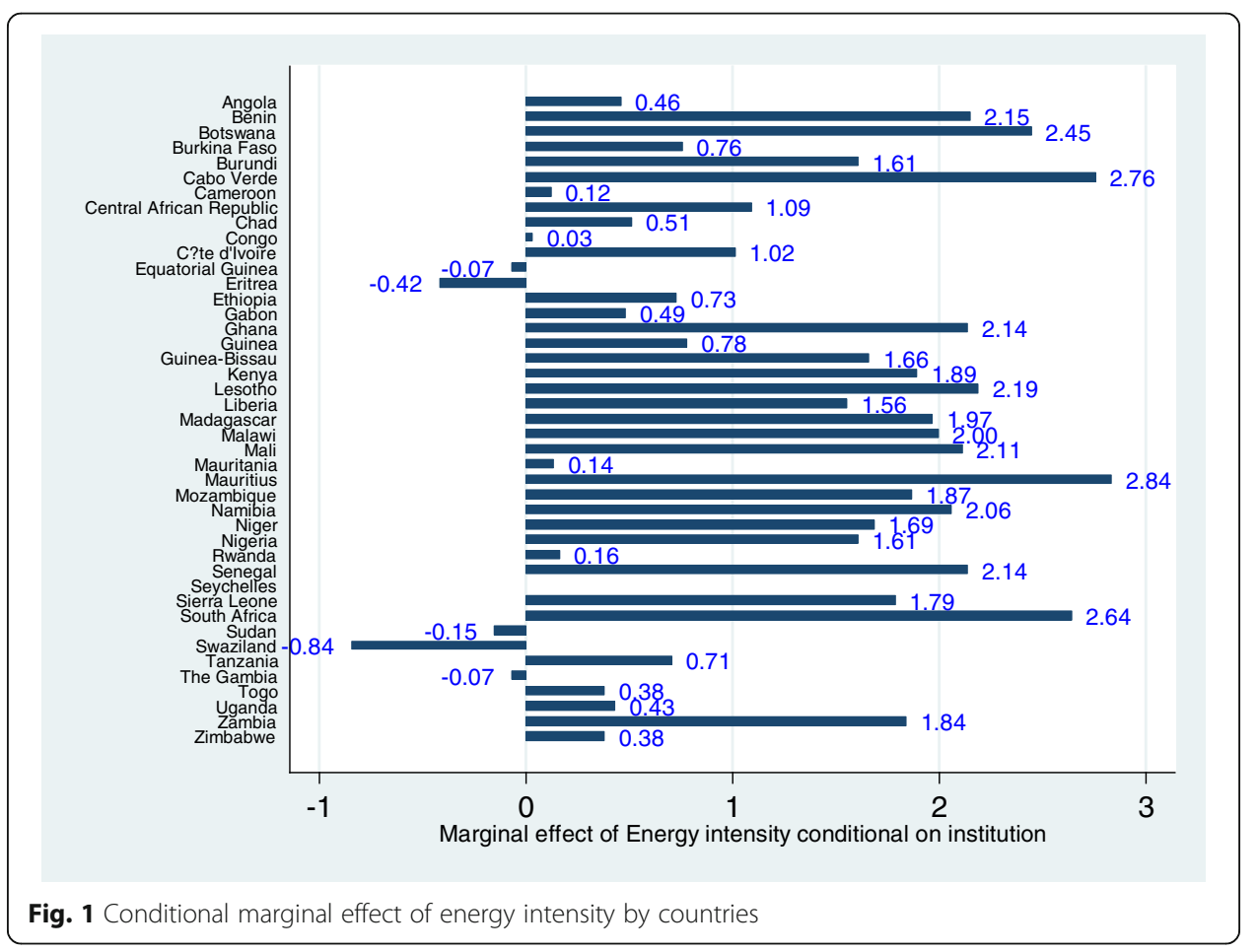


the estimated model may suffer from a reverse causality issue and, consequently, create model identification problem. To deal with this problem, in model 3 of Table 4, we included the lag of energy intensity instead of the contemporaneously data. This theoretically breaks the causality from financial development to energy intensity as the development of the financial sector in the present year can only have meaningful impact (if any) on current and future energy use behavior. However, the causality from previous energy intensity to current financial development is plausible. As shown in the table, the results remain very robust. The effect of energy intensity on bank profitability is differentiated between autocratic and democratic political regimes, with the former more likely to translate energy efficiency improvements into higher bank profitability.

\section{Sensitivity analysis}

As shown in models 4-6, we further performed sensitivity analysis on the results. The growth of the service sector has positive implications on the overall growth of the economy and vice versa. Hence, the possible correlation between the growth of the service sector and the overall economy could cause multicollinearity and, thereby, create parameter identification issue. Therefore, in model 4 of Table 4, we dropped the share of the service sector value-added as percent of GDP from the model. The direct effect of energy intensity is negative, which confirms the earlier claim that, in an autocratic regime, improving energy efficiency (i.e., reducing energy intensity) is more likely to increase commercial banks' profitability. However, the indirect effect is positive, which means that, in a democratic regime, improvement in energy efficiency is less likely to promote higher bank profit.

Given that price affects energy intensity, there could be a potential correlation problem. Additionally, improvement in energy efficiency reduces the energy expenditure incidence on consumers and prevents additional investment in generation capacity. Although the former can enhance the consumption basket of consumers and thereby improve upon their welfare, the latter leads to significant national savings, which could be used in other productive sectors of the economy to promote economic growth. Likewise, the growth of the economy can also trigger energy efficiency investment and thereby cause energy intensity to reduce. This implies that economic growth and energy intensity could confound their effects. In models 5 and 6, we dropped the inflation and economic growth variable from the model. Albeit, the effect of energy efficiency on profitability is differentiated between autocratic and democratic political regimes, it is statistically weak.

\section{Explanation of the controlled variables}

On the controls, the coefficient of the lag dependent variable is significantly positive and consistent in Table 4. Thus, there is a significant inertia in bank profit, but the extent of the inertia or persistence in bank profit is small. This implies that abnormal profits enjoyed by commercial banks in the banking industry are temporal and not permanent. In other words, the competition in the banking industry in SSA is intense. This finding contradicts the findings of Flamini et al. (2009). However, the findings of low persistence confirm the claim that, in developing countries like SSA countries, the degree of persistence in profits is lower compared with developed economies because of the lower sunk cost of entry, faster economic growth, and the existence of large conglomerate firms, which together increase the intensity of competition (Goddard et al. 2011; Stephan and Tsapin 2008). 
An increase in commercial banks' lending has a consistent significant positive influence on banks' profitability; however, higher credit risk significantly reduces the profitability of banks. The negative effect of credit risk is also confirmed by Chowdhury et al. (2016) and Nawaz and Haniffa (2017), but contrasts the findings of Flamini et al. (2009). The size of banks has a significant positive effect on their performance, which confirms the results of Nawaz and Haniffa (2017), Flamini et al. (2009), and Seemule et al. (2017); however, this finding is at variance with those of Obamuyi (2013) and Siddik et al. (2016). The positive effect of size represents the existence of economies of scale for large banks. The presence of economies of scale help decrease the dependence of commercial banks on external finances and rather increases their reliance on internal finances. As a result, they become immune to external shocks which helps improve their profitability. Managerial inefficiency negatively affects banks' performance. Thus, an improvement in operational efficiency will help improve the performance of commercial banks in the region, confirming the findings of Seemule et al. (2017) and Chowdhury et al. (2016).

A more stable financial sector affects positively the profitability of banks. Conversely, a fragile banking sector reduces banks' ability to finance productive investments. Furthermore, GDP growth and inflation have a significant positive effect on profitability. This implies that the goal of economic growth is consistent with the goal of banking sector development. The positive role of GDP growth confirms the findings of Obamuyi (2013), Flamini et al. (2009) and Zeitun (2012), but contrasts the findings of Seemule et al. (2017) and Siddik et al. (2016). Inflation has both revenue and cost implications for the banks. When inflation is anticipated, banks are able to adjust the lending rate to reflect current prices. As a result, there is no loss in real value for the banks. Given that demand for credit remains inelastic (which is the case for customers in Africa with limited financing sources), returns on credit will increase and lead to higher profit. The positive inflation effect confirms the findings of Athanasoglou et al. (2006) and Tan and Floros (2012), but contrasts the findings of Chowdhury et al. (2016) and Zeitun (2012). The service sector value-added has a significant positive effect on profitability, that is, banks might benefit from sound sector-wide government policies.

\section{Robustness check}

Table 5 contains the results when the petroleum energy intensity indicator is used as the dependent variable. Apart from being more appealing from a policy perspective, this partially addresses the aggregation issue. Fossil fuel energy constitutes a significant share in total energy consumption in the sub-region; it is the single largest contributor to atmospheric greenhouse gas emission in the region. Moreover, it is a significant generation source for both off-grid and grid electricity. Thus, achieving efficiency in the use of fossil fuel (i.e., reducing fossil fuel energy intensity) will contribute positively both to energy security and environmental quality in the sub-region. The models passed the Sargan instrument validity test. In addition, the results passed the serial correlation test. The Pesaran's (2004, 2015) cross-sectional dependence test fail to accept the null hypothesis of residuals' cross-sectional independence. Lastly, the null hypothesis of unit root in the residuals from both models is rejected at $1 \%$ statistical significance level. Thus, the residuals from these system GMM models are stationary. Here as well, the discussion is based on the general model, whose results are shown in column 4. 
Table 5 Sensitivity Analysis

\begin{tabular}{|c|c|c|c|c|c|}
\hline & \multicolumn{5}{|c|}{ Petroleum energy intensity } \\
\hline & $(1)$ & $(2)$ & (3) & (4) & (5) \\
\hline VARIABLES & Uncond. & EIPT\&Polity2 & EIPT\&Polity2 & EIPT\&Polity2 & EIPT\&Polity2 \\
\hline \multirow[t]{2}{*}{ L.ROA } & $0.187^{* * *}$ & $0.153^{* * *}$ & $0.169^{* * *}$ & $0.143^{* * *}$ & $0.148^{* * *}$ \\
\hline & $(0.0224)$ & $(0.0177)$ & (0.0193) & $(0.0231)$ & $(0.0272)$ \\
\hline \multirow[t]{2}{*}{ CreditGrowth (lag) } & $1.771^{* * *}$ & $1.555^{* * *}$ & $1.643^{* * *}$ & $2.776^{* * *}$ & $2.788^{* * *}$ \\
\hline & $(0.181)$ & $(0.196)$ & $(0.202)$ & $(0.261)$ & $(0.269)$ \\
\hline \multirow[t]{2}{*}{ Size } & $0.171^{* * *}$ & $0.191^{* * *}$ & $0.178^{* * *}$ & $0.256^{* * *}$ & $0.258^{* * *}$ \\
\hline & $(0.00708)$ & $(0.0112)$ & $(0.0189)$ & $(0.0230)$ & $(0.0233)$ \\
\hline \multirow[t]{2}{*}{ Risk } & -0.00869 & -0.0144 & $-0.0162^{* * *}$ & 0.00943 & $0.00958^{*}$ \\
\hline & $(0.00879)$ & $(0.00917)$ & $(0.00454)$ & $(0.00602)$ & $(0.00546)$ \\
\hline \multirow[t]{2}{*}{ MIE } & $-0.024^{* * *}$ & $-0.0231^{* * *}$ & $-0.0241^{* * *}$ & $-0.0571^{* * *}$ & $-0.0570^{* * *}$ \\
\hline & $(0.00359)$ & $(0.00292)$ & $(0.00246)$ & $(0.00469)$ & $(0.00515)$ \\
\hline \multirow[t]{2}{*}{ FG } & $0.0335^{* * *}$ & -0.00829 & 0.00851 & $-0.0941^{* * *}$ & $-0.0919^{* * *}$ \\
\hline & $(0.00848)$ & $(0.00923)$ & $(0.0106)$ & $(0.0228)$ & $(0.0205)$ \\
\hline \multirow[t]{2}{*}{ GDPgrowth } & $0.0997^{* * *}$ & $0.111^{* * *}$ & $0.0799 * * *$ & $0.0321^{* * *}$ & - \\
\hline & $(0.00783)$ & $(0.00690)$ & $(0.00723)$ & $(0.00556)$ & \\
\hline \multirow[t]{2}{*}{ Infl } & $0.0419^{* * *}$ & $0.0413^{* * *}$ & $0.0331^{* * *}$ & - & - \\
\hline & $(0.00576)$ & $(0.00600)$ & $(0.00104)$ & & \\
\hline \multirow[t]{2}{*}{ Ineipt } & $-0.612^{* * *}$ & $-4.132^{* * *}$ & $-3.398^{* * *}$ & $-4.285^{* * *}$ & $-4.238^{* * *}$ \\
\hline & $(0.158)$ & $(0.492)$ & $(0.390)$ & $(0.566)$ & $(0.596)$ \\
\hline \multirow[t]{2}{*}{ InSSH } & $5.289^{* * *}$ & $5.929^{* * *}$ & - & - & - \\
\hline & $(0.569)$ & $(0.571)$ & & & \\
\hline \multirow[t]{2}{*}{ Polity2 } & 0.223 & $82.19^{* * *}$ & $72.69^{* * *}$ & $99.81^{* * *}$ & $93.70^{* * *}$ \\
\hline & $(0.509)$ & $(12.53)$ & (12.29) & $(13.45)$ & (13.76) \\
\hline \multirow[t]{2}{*}{ Polity2*/neipt } & - & $6.476^{* * *}$ & $5.619^{* * *}$ & $7.836^{* * *}$ & $7.332^{* * *}$ \\
\hline & & $(0.957)$ & $(0.936)$ & $(1.049)$ & $(1.079)$ \\
\hline \multirow[t]{2}{*}{ Total effect of Ineipt } & - & -0.419 & -0.177 & 0.208 & -0.034 \\
\hline & & $(0.282)$ & $(0.536)$ & $(0.602)$ & $(0.619)$ \\
\hline \multirow[t]{2}{*}{ Constant } & $-14.77^{* * *}$ & $-75.18^{* * *}$ & $-43.70^{* * *}$ & $-51.13^{* * *}$ & $-50.70^{* * *}$ \\
\hline & $(3.226)$ & $(7.223)$ & $(5.213)$ & $(7.228)$ & $(7.553)$ \\
\hline Observations & 329 & 329 & 374 & 377 & 377 \\
\hline ID & 37 & 37 & 39 & 40 & (40) \\
\hline Sargan's test (S) & $24.95(25)$ & $25.79(25)$ & $22.18(25)$ & $25.30(25)$ & $25.48(25)$ \\
\hline 1st order autocor. & $-1.94^{*}$ & $-1.88^{*}$ & $-2.11^{* *}$ & $-2.16^{* *}$ & $-2.13^{* *}$ \\
\hline 2nd order autocor. & -0.77 & -0.72 & -1.10 & -0.91 & -0.94 \\
\hline$C D$ & 0.032 & 0.442 & 0.265 & 0.700 & 1.253 \\
\hline ADF & 0.000 & 0.000 & 0.000 & 0.000 & 0.000 \\
\hline
\end{tabular}

Standard errors in parentheses

${ }^{* * *} p<0.01,{ }^{* *} p<0.05,{ }^{*} p<0.1$

The direct effect of petroleum energy intensity on commercial bank profits is significantly negative, confirming the earlier claim. However, the indirect effect via democratic regime is positive. These results suggest that, relatively, energy efficiency is more likely to enhance the profitability of banks in an autocratic regime than democratic 
one. Figure 2 shows the marginal effects of energy efficiency improvements on commercial banks' profitability conditioned on the political regime. There is an obvious heterogeneity regarding the effect of in energy efficiency enhancement on commercial banks' profitability. The results indicate that energy efficiency enhancements in countries like Angola, Burkina Faso, Cameroon, Central Africa Republic, Chad, Congo, Cote d'Ivoire, Equatorial Guinea, Eritrea, Ethiopia, Gabon, Guinea, Mauritania, Rwanda, Sudan, Swaziland, Zimbabwe, Tanzania, the Gambia, Togo, and Uganda would drive the profitability of commercial banks. Some degree of dictatorship in the governance systems exists in many of these countries. Dictatorship or autocracy minimizes the problems of "grandfathering" and weakens the powers of strong interest or pressure interest groups to boycott or resist government programs for promoting energy efficiency.

Furthermore, columns 3 to 5 show the results when we perform sensitivity analysis on the results. The findings remain very robust and the statistical power of the relationship improves significantly compared with the case when aggregate energy intensity is used. This is evidenced in the size of the coefficients (both direct and indirect), the consistency in the signs of the direct effect, and the highly statistically significant nature of the relationship. In contrast, the conditional marginal effect of energy efficiency on profitability for democratic matured economies, such as Ghana, South Africa and Nigeria, is positive, confirming that energy efficiency improvement is less likely to drive banks' profitability in such political institutional regime.

On the control variables, there is an evidence of significant inertia in profitability; however, its degree is small. Internal factors, such as credit growth and bank size, have significant positive effects on profitability, but the effect of higher credit risk and managerial inefficiency is negative. Regarding external factors, GDP growth, inflation, and

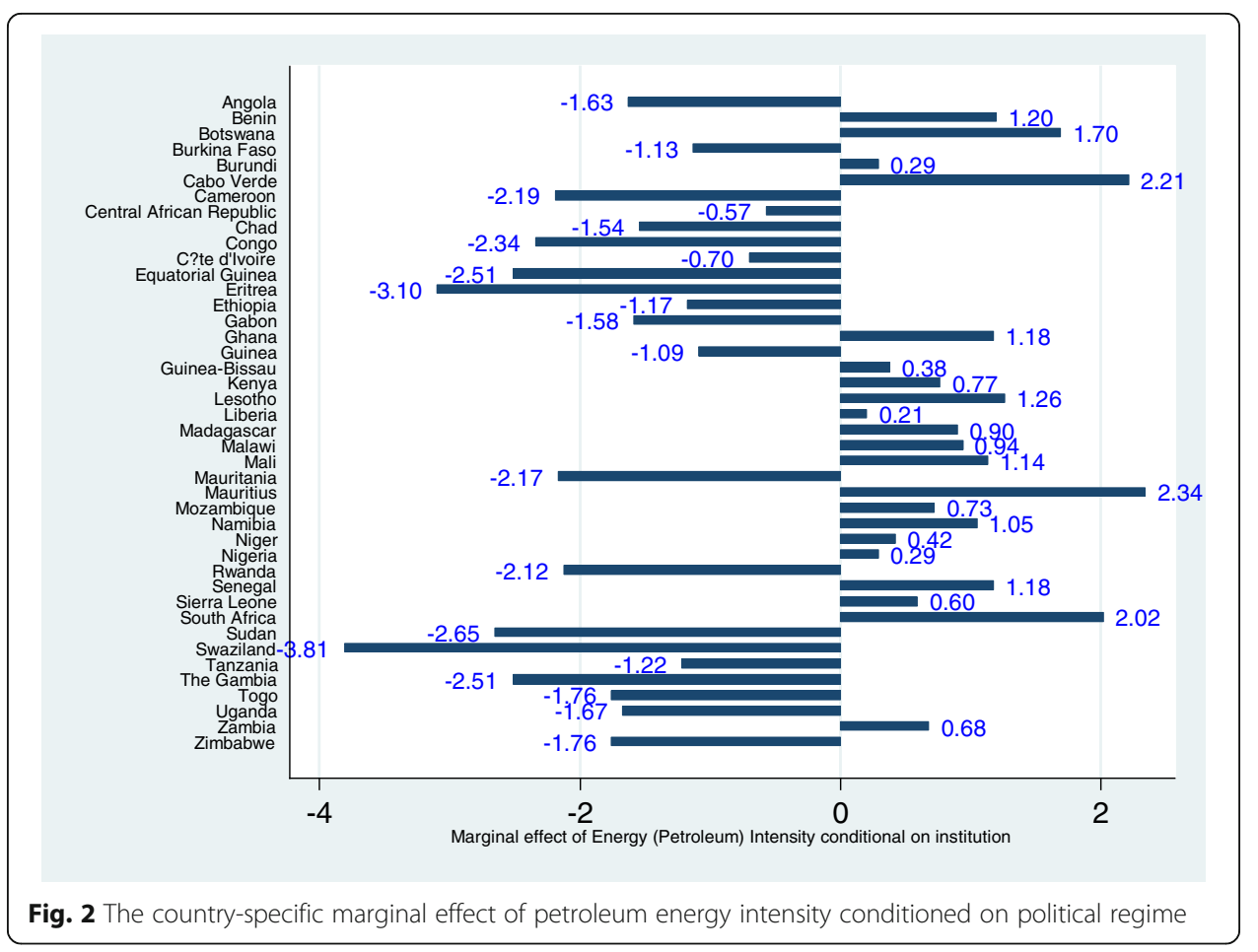


share of the service sector output in total output have significant positive effects on commercial banks' profitability. This confirms the earlier result that both internal and external factors play significant roles in explaining commercial banks' profitability.

\section{Conclusions and policy recommendations}

The growth of the financial sector is critical to economic growth. Albeit, in Africa, the growth of the financial sector has translated into real sector and economic-wide growth, the financial sector is not well developed as compared to Asia, America, and Europe. In this study, we investigate the problem of bank profitability (an indicator of financial sector performance) from the perspective of energy efficiency given different political regimes in SSA countries. The study uses bank-level data compiled by Andrianova et al. (2015), consisting of 43 SSA countries for the period 1998-2012 and the simultaneous system-GMM technique. The following results emerged from the study.

We found that improvement in energy efficiency (i.e., lower energy intensity) drives the profitability of commercial banks upward; however, such trend is more probable in a political regime with centralization of power than in a political regime with decentralization of power. This conclusion professes the following policy interventions. Commercial banks should include the energy utilization behavior of their clients in their credit valuation. This could help the banks design tailor-specific interest rates to deal with the different risk profiles of their clients. On the borrowers' side, such an initiative by the bank can lead to more informed decisions on energy efficiency investment. On the part of the government, the positive effect of energy efficiency on profitability suggests that the government should green-label banks (with financial rewards) that provide credit facilities for energy efficiency investments. In a democratic political regime, the agenda of energy efficiency should be pursued aggressively without losing sight of creating a political environment that is devoid of any "grandfathering system".

Certainly, promoting energy efficiency alone cannot be the panacea to raise the profitability of commercial banks in SSA. As revealed in this study, bank-specific and external factors play significant roles in explaining banks' profitability. To increase profit, credit risk policies and operational efficiency should be pursued aggressively by banks in the sub-region. Creating a more stable financial sector is also necessary. At the macroeconomic level, the goal of economic growth is compatible with commercial bank development. Therefore, prudent macroeconomic policies that lead to the growth of the economy should receive greater attention.

As current studies on the nexus between the financial sector performance and energy efficiency remain scanty, more empirical work is required to confirm the claim of the profitability-induced effect of energy efficiency. The conditional effect of energy efficiency as found in this study suggests that the analysis of the energy efficiency effect on banks' profitability or the financial sector performance can be highly contextualized. Therefore, future studies should take cognizance of this fact. Moreover, this study used the energy intensity indicator as a measure of energy efficiency, which has been criticized in the literature. Albeit, in this study, the authors tried to capture the efficiency component of energy intensity by controlling for other factors, such as shifts in economic structure and pricing regimes, the list might not be exhaustive, leaving room for some biases in our results. To improve the results, future studies can first model energy efficiency, using either parametric or nonparametric methods and then use the estimated efficiency scores in a profitability model. 


\section{Acknowledgements}

This study used a dataset compiled by Andrianova et al. (2015). The authors are grateful to the authors for making this information available. The authors wish to thank three anonymous reviewers and the editor for their constructive comments, which have improved the earlier version of this article. The usual disclaimer applies.

\section{Authors' contributions}

All three authors were involved in the conceptualization of the problem and made equal contributions in the carrying out and writing of the final paper. The author(s) read and approved the final manuscript.

\section{Funding}

This study receive no funding support.

\section{Availability of data and materials}

Codes and data used for this paper are available upon request.

\section{Competing interests}

There are no competing interests.

\section{Author details}

'Department of Development Policy, School of Public Service and Governance, Ghana Institute of Management and Public Administration (GIMPA), Accra, Ghana. ${ }^{2}$ Environment for Development, University of Gothenburg, Gothenburg, Sweden. ${ }^{3}$ Department of Business Administration, Technology and Social Sciences, Lulea University of Technology, Lulea, Sweden. ${ }^{4}$ Department of Economics, Swedish University of Agricultural Sciences, Uppsala, Sweden.

Received: 12 December 2019 Accepted: 12 August 2020

Published online: 17 September 2020

\section{References}

Abimbola A (2002) Pressure groups and the democratic process in Nigeria (1979-1993). Nordic J Afr Stud 11(1):38-47 Adom PK (2018) The long-run effects of political regimes and economic openness on energy intensity. Afr Dev Rev 30(4): 399-409

Adom PK, Amakye K, Abrokwah K, Quaidoo C (2018) Estimate of transient and persistent energy efficiency in Africa: a stochastic frontier analysis. Energy Convers Manag 166C:556-568

Adom PK, Opoku EEO, Yan IK-M (2019b) Energy demand -FDI nexus in Africa: do FDIs induce dichotomous paths? Energy Econ 81:928-941

Adom PK, Owusu M, Agradi MP (2019a) Does financial development lower energy intensity? Front Energy. https://doi.org/10. 1007/s11708-019-0619-X

Agyarko K (2016) The success story of the Ghana refrigerator efficiency project implemented by the energy commission. Energy Commission, Accra

Allen F, Carletti E, Cull R, Qian QJ, Senbet LW, Valenzuela P (2016) Resolving the African financial development gap: crosscountry comparisons and a within-country study of Kenya. In: Edwards S, Johnson S, Weil D (eds) African successes: modernization and development. NBER Volume; University of Chicago Press, USA.

Alsaleh M, Abdul-Rahim AS (2019) Financial development and bioenergy consumption in the EU 28 region: evidence from panel autoregressive distributed lag bound approach. Resources 8:44

Amuakwa-Mensah F, Adom PK (2017) Quality of institution and the FEG (Forest, energy intensity and globalisation)environment relationship in sub-Saharan Africa. Environ Sci Pollut Res. https://doi.org/10.1007/s11356-017-9300-2

Amuakwa-Mensah F, Klege RA, Adom PK, Hagan E, Amoah AA (2018) Unveiling the energy saving role of banking performance in sub-Saharan Africa energy econ, vol 74, pp 828-842

Andrianova, Svetlana, Baltagi, Badi, Beck, Thorsten, Demetriades, Panicos, Fielding, David, Hall, Stephen, Koch, Steven, Lensink, Robert, Rewilak, Johan, Rousseau, Peter., 2015. A new international database on financial fragility. Discussion paper 15/18, Department of Economics, University of Leicester. http://www.le.ac.uk/economics/research/RePEc/lec/leecon/dp15-18.pdf

Arellano M, Bond S (1991) Some tests of specification for panel data: Monte Carlo evidence and an application to employment equations. Rev Econ Stud 58(2):277-297

Asma I, Fadli A, Noor T (2011) Determinant of Islamic banking institutions' profitability in Malaysia. Word applied sciences journal, Vol. 12, 1 July

Athanasoglou P, Delis M, Staikouras C (2006) Determinants of bank profitability in the southern eastern European region. Working paper no. 47, bank of Greece, Athens

Bennett, K. (2001). Energy efficiency in Africa for sustainable development: a south African perspective. Energy Research Institute, University of Cape Town, South Africa

Blundell R, Bond S (1998) Initial conditions and moment restrictions in dynamic panel data models. J Econ 87(1):115-143

Bougatef K (2017) Determinants of bank profitability in Tunisia: does corruption matter? J Money Laundering Control 20(1): $70-78$

Bunse K, Vodicka M, Schönsleben P, Brülhart M, Ernst FO (2011) Integrating energy efficiency performance in production management-gap analysis between industrial needs and scientific literature. J Clean Prod 19:667-679

Capraru B, Ihnatov I (2014) Bank's profitability in selected central and eastern European countries. Procedia Econ Finance 16: 587-591

Carr FM, Beese JA (2008) How raising oil prices caused home foreclosures from 2005-2008. Proc Allied Acad 15(2):70-73 
Chowdhury MAF, Haque MM, Masih M (2016) Re-examining the determinants of Islamic Bank performance: new evidence from dynamic GMM, Quantile Regression and Wavelet Coherence Approaches. Emerg Markets Finance Trade. https://doi. org/10.1080/1540496X.2016.1250076

Chowdhury MAF, Rasid MESM (2015) The determinants of the profitability of Islamic banks: a cross-sectional study from Asia and Africa. Int J Bus Glob 15(3):375

De Hoyos RE, Sarafidis V (2006) Testing for Cross-Sectional Dependence in Panel-Data Models. Stata J 6(4):482-496

European Investment Bank (2015). Recent trends in banking in sub-Saharan Africa from financing to investment. Retrieved on 23/08/2017 from http://www.eib.org/attachments/efs/economic_report_banking_africa_from_financing_to_investment_ en.pdf

Fan LW, Pan SJ, Liu GQ, Zhou P (2017) Does energy efficiency affect financial performance? Evidence from Chinese energyintensive firms. J Clean Prod 151:53-59

Fawkes H (2005) Energy efficiency in south African industry. J Energy South Africa 16(4):18-25

Flamini V, McDonald C, Schumacher L (2009) The determinants of commercial bank profitability in sub-Saharan Africa. Working Paper No. WP/09/15. IMF, Washington, DC

Fredriksson PG, Vollebergh HRJ, Dijkgraaf E (2004) Corruption and energy efficiency in OECD countries: theory and evidence. J Environ Econ Manag 47(2):207-231.

Gennaioli C, Tavoni M (2011) Clean or "Dirty" Energy: Evidence on a Renewable Energy Resource Curse (SSRN Scholarly Paper No. ID 1920145). Social Science Research Network, Rochester, NY.

Goddard JM, Liu H, Molyneux P, Wilson JOS (2011) The persistence of bank profit. J Bank Financ 35(11):2881-2890

Green, C. J (2013). Financial reform and financial development in Africa. Commissioned Proposal prepared for AERC

Izhar H, Asutay M (2007) Estimating the profitability of Islamic banking: evidence from bank Muamalat Indonesia. Rev Islamic Econ 11(2):17

Karim BK et al (2010) Bank-specific, industry-specific and macroeconomic determinants of African Islamic Banks' profitability. Int J Bus Manag Sci 3(1):39-56

Kaufmann et al (2011) Do household energy expenditures affect mortgage delinquency rates? Energy Econ 33(2):188-194

Kosmidou K (2008) The determinants of banks' profits in Greece during the period of EU financial integration. Manag Financ 34(3):146-159

Kosmidou K, Tanna S, Pasiouras F (2008) Determinants of profitability of domestic UK commercial banks: panel evidence from the period 1995-2002. (economics, finance and accounting applied research working paper series no. RP08-4). Coventry University, Coventry http://wwwm.coventry.ac.uk/bes/cubs/aboutthebusinessschool/Economicsfinanceandaccounting/ Pages/AppliedResearchWorkingPapers.aspx

Kou G, Peng Y, Wang G (2014) Evaluation of clustering algorithms for financial risk analysis using MCDM methods. Inf Sci 275: $1-12$

Mlachila M, Park SG, Yabara M (2013) Banking in Sub-Saharan Africa: the macroeconomic context. IMF, African Department 13/03

Muñoz S, Jahjah S, Cihák M, Sharifuddin ST, Tintchev K (2012) Financial Stability Reports: What Are they Good for? IMF Working Papers 12(1):1.

Nawaz T, Haniffa R (2017) Determinants of financial performance of Islamic banks: an intellectual capital perspective. J Islamic Account Bus Res 8(2):130-142. https://doi.org/10.1108/JIABR-06-2016-0071

Neidell, M. (2017). Air pollution and worker productivity. IZA world of labor, ISSN 2054-9571, Institute for the study of labor (IZA), Bonn, Iss. 363, https://doi.org/10.15185/izawol.363

Nikolaidou E, Vogiazas S (2017) Credit risk determinants in sub-Saharan banking system: evidence from five countries and lessons learnt from central east and south east European countries. Rev Dev Finance 7:52-63

Nyantakyi EB., Sy M (2015). The banking system in Africa: Main facts and challenges. African Economic Brief volume 6 issue 5 . African Development Bank

Obamuyi TM (2013) Determinants of banks' profitability in a developing economy: evidence from Nigeria. Organ Mark Emerg Econ 4(2-8):97-111

Olson D, Zoubi TA (2011) Efficiency and bank profitability in MENA countries. Emerg Mark Rev 12:94-110

Pesaran MH (2004) General diagnostic tests for cross section dependence in panels. University of Cambridge, Faculty of Economics, Cambridge working papers in economics no. 0435

Pesaran MH (2007) A simple panel unit root test in the presence of cross-section dependence. J Appl Econ 22:265-312

Pesaran MH (2015) Testing weak cross-sectional dependence in large panels. Econ Rev 34(6-10):1089-1117

Petria N, Capraru B, Ihnatov I (2015) Determinants of banks' profitability: Evidence from EU 27 banking systems. Procedia Econ Finance 20:518-524

Ramos-Real FJ, Marrero GA, Álvarez-Albelo CD (2015) Energy intensity, technology and institutions. Presented at the 33rd International Association for Energy Economics (IAEE). Pennsylvania, Pittsburgh

Sadorsky P (2013) Do urbanization and industrialization affect energy intensity in developing countries? Energy Econ 37:5259

Seemule M, Sinha N, Ndlou T (2017) Determinants of commercial banks profitability in Botswana: An empirical analysis Senbet LW, Otchere I (2010) African stock markets. In: African finance in the 21st century, IMF volume (Palgrav; Eds. Marc Quintyn and Genevieve Verdier)

Siddik MNAS, Sun G, Kabiraj S, Shanmugan J, Yanjuan C (2016) Impacts of e-banking on performance of banks in a developing economy: empirical evidence from Bangladesh. J Bus Econ Manag 17(6):1066-1080. https://doi.org/10.3846/ 16111699.2015 .1068219

Sleuwagenn L, Goedhuys M (2003) Technical efficiency, market share and profitability of manufacturing firms in cote d'Ivoire: the technology gap. Camb J Econ 27(6):851-866

Stephan A, Tsapin A (2008) Persistence and determinants of firm profit in emerging markets. Appl Econ Q 54:231-253

Subrahmanya MB (2006a) Energy intensity and economic performance in small scale bricks and foundry clusters in India: does energy intensity matter? Energy Policy 34:489-497

Subrahmanya MB (2006b) Labour productivity, energy intensity and economic performance in small enterprises: a study of brick enterprises cluster in India. Energy Conversion Manag 47:763-777 
Sufian F (2012) Determinants of bank profitability in developing economies: empirical evidence from the south Asian banking sectors. Contemp South Asia 20(3):375-399

Tan Y, Floros C (2012) Bank profitability and inflation: the case of China. J Econ Stud 39(6):675-696

Wang H, Kou G, Peng Y (2020) Multi-class misclassification cost matrix for credit ratings in peer-to-peer lending. J Oper Res Soc. https://doi.org/10.1080/01605682.2019.1705193

Windmeijer F (2005) A finite sample correction for the variance of linear efficient two-step GMM estimators. J Econ 126(1):25-51

Yang M (2010) Energy efficiency improving opportunities in a large Chinese shoemaking enterprise. Energy Policy 38:452-462

Zhang D, Broadstock DC (2016) Club Convergence in the Energy Intensity of China. Energy J 37(3):137-158

Zeitun R (2012) Determinants of Islamic and commercial banks performance in GCC countries using panel data analysis. Global Economy Finance J 5(1):53-72

Zivin JG, Neidell M (2012) The impact of pollution on worker productivity. Am Econ Rev 102(7):3652-3673

Publisher's Note

Springer Nature remains neutral with regard to jurisdictional claims in published maps and institutional affiliations.

Submit your manuscript to a SpringerOpen ${ }^{0}$ journal and benefit from:

- Convenient online submission

- Rigorous peer review

- Open access: articles freely available online

- High visibility within the field

- Retaining the copyright to your article

Submit your next manuscript at $>$ springeropen.com 